Article

\title{
The Economics of Classroom 3-D Printing of Open-Source Digital Designs of Learning Aids
}

\author{
Nicole Gallup ${ }^{1}$ and Joshua M. Pearce $2,3,4, *$ D \\ 1 Department of Biomedical Engineering and Mechanical Engineering, Michigan Technological University, \\ Houghton, MI 49931, USA; ngallup@mtu.edu \\ 2 Department of Materials Science \& Engineering, Michigan Technological University, Houghton, MI 49931, USA \\ 3 Department of Electrical \& Computer Engineering, Michigan Technological University, Houghton, \\ MI 49931, USA \\ 4 Department of Electronics and Nanoengineering, School of Electrical Engineering, Aalto University, \\ FI-00076 Espoo, Finland \\ * Correspondence: pearce@mtu.edu
}

Received: 31 October 2020; Accepted: 25 November 2020; Published: 29 November 2020

\begin{abstract}
While schools struggle financially, capital for purchasing physical learning aids is often cut. To determine if costs could be reduced for learning aids, this study analyzed classroom-based distributed digital manufacturing using 3-D printing of open-source learning aid designs. Learning aid designs are analyzed in detail for their economic viability considering printing and assembly costs with purchased components and compared to equivalent or inferior commercial products available on Amazon. The results show current open-source 3-D printers are capable of manufacturing useful learning aids and that doing so provides high economic savings in the classroom. Overall, the average learning aid would save teachers $86 \%$ when fabricating it themselves. The results show that the average design evaluated was downloaded over 1,500 times and the average savings per year per open-source learning aid design was USD 11,822. To date, the 38 learning aid designs evaluated in this study saved over USD 45,000 each and the total of all of them saved the international educational community over USD 1.7 million. It is clear that investing in the development of open-source learning aids for students provides a return on investment (ROI) for investors hoping to improve education, on average, of more than $100 \%$.
\end{abstract}

Keywords: learning aid; distributed manufacturing; 3-D printing; economics; open source; digital designs; 3-D printing; teaching tools; education aid; open-source designs

\section{Introduction}

Schools throughout the world in both developing countries [1] and even in wealthy countries like the U.S. have been chronically underfunded [2-4]. This presents challenges to teachers in optimizing the education of their pupils at every level. Schools under financial stress are trying to find ways to deliver high-quality education for the lowest possible cost [5]. Capital costs in particular are often the first to be cut [6], which largely limit teachers' abilities to afford hardware-based learning aids [7]. These teaching and learning aids tend to be expensive and only available to wealthy school districts in the developed world [8]. Engaging teaching and learning aids were found to be particularly effective for special education students [8], such as for visually impaired people, for whom underfunding is widespread.

A rapidly expanding means to reduce prices for consumer goods is distributed manufacturing with digital technologies such as 3-D printers [9-11]. 3-D printers are already being increasingly used for industrial additive manufacturing [12], but they can also be used for distributed manufacturing by 
local businesses [13-15], libraries [16-18], fab labs [19,20], makerspaces [21] and even individuals [22]. Several studies have shown that 3-D printers can be used to save substantial money at the household level by using free designs [23-26]. This was possible because of recent applications of the free and open source hardware (FOSH) design methodology [27-29] that have decreased the costs of self-replicating rapid prototyper (RepRap) 3-D printers (e.g., 3-D printers that can largely print their own components) [30-32].

These 3-D printer cost reductions also have enabled 3-D printing education applications, which are now broad and widespread [33], including: medical education [34,35], in particular anatomy [36,37] and prosthetic applications [38], special education [39], cultural heritage [40], geoscience education [41], engineering [42,43], STEM education [44-46], sustainable development education [47] and teacher education for digital design $[48,49]$. Robot hardware has been designed for education, ranging from electromagnetic field mapping robots [50], to Shybo, a low-anthropomorphic robot for children [51], and YOLO, a creativity-stimulating robot for children [52]. 3-D printers, largely direct technical decedents of RepRap-based technology, cover the full spectrum of children's education, including primary and elementary school [53,54], middle school [55], secondary/high school [56,57] and combinations of the three [58]. In many of the research articles dedicated to the applications of open-source 3-D printing in the classroom, the potential economic savings were either ignored completely or briefly commented upon. Thus, it is not clear if the economic savings found for distributed manufacturing of mass consumer products also apply to open-source digital designs of more limited production learning aids.

To fill this knowledge gap, this study analyzes the economics of classroom-based 3-D printing of open-source digital designs of learning aids for the classroom itself. In order to assess if such a methodology is technically and financially viable for teachers to implement, this study specifically focuses on the use of an open-source desktop 3-D printer, using guaranteed 3-D printable open-source designs of teaching/learning aids from a free repository. Five example learning aids are evaluated in detail, including functionality, physically printed/calculated mass ratios and 3-D printer energy consumption to determine a USD $/ \mathrm{kg}$ costs for printing. Next, an additional 33 different learning aid designs are analyzed in detail for their economic viability considering printing and assembly costs with purchased components and compared to equivalent or inferior commercial products available on Amazon. The percent savings are calculated. The savings for individual teachers are scaled to the world based on demonstrated download volume rates and the results are evaluated to determine the potential for distributed manufacturing to assist teachers in reducing the cost of education in their classroom.

\section{Materials and Methods}

Although many open-source 3-D printing repositories can be used to find educational aids, the database used was MyMiniFactory [59] due to its wide range of products and guaranteed 3-D printable designs (e.g., all designs have been verified to have been printed). The teaching/learning aids chosen were determined by each subject with various age groups: kindergarten, elementary school, middle school and high school. Within the middle school and high school groups, subcategories were chosen based on what was available on MyMiniFactory, including: biology, chemistry, design and technology, history, geography, mathematics and physics. Two designs were chosen for each subcategory. Those with higher numbers of downloads and usability were looked into more closely. An Amazon equivalent was also needed to accompany the aid in order for it to be chosen for testing. Amazon was selected here as the retailer because of its well-established competitive approach, which reduces costs for consumers [60-62] and has made it one of the world's largest retailers. The URLs for the open-source designs as well as the corresponding Amazon products are available in Appendix A.

For this analysis of the educational aids, it was imperative that the devices and materials used were easily accessible for all students and educators. Any RepRap-class FFF 3-D printer can be used with the designs evaluated. However, a Lulzbot Taz 6 (Aleph Objects, Loveland, CO, USA) was selected 
due to the ease of use (auto bed leveling), high resolution capabilities, reliability, support of open source hardware and software and the ability to work with a variety of operating systems, which may be determined by the school district and not the teacher. In addition, it can print from an SD card, enabling it to be un-tethered from a computer.

Three-millimeter polylactic acid (PLA) was selected as the filament because it is the most accessible thermoplastic 3-D printing material. PLA has less warping during printing and less emissions than other materials, such as the second most common 3-D printing plastic (acrylonitrile butadiene styrene or ABS). PLA is also synthesized from a renewable corn-based resin, making it environmentally friendly, as it is non-toxic and biodegradable [63]. These properties make it suitable for use in the classroom with small children. Various colors of PLA were supplied by Hatchbox and sourced from Amazon.com. Although the color can impact the mechanical strength of PLA [64], the strength was deemed more than adequate for all of the learning aid applications.

Five of the most representative aids detailed in Table 1 from various categories were chosen to determine USD/g for printing considering the cost of filament and electricity consumption, including: A clock, a brain, a Pythagorean theorem visual aid, a spinal cord and a combustion engine. The mass for each was determined by printing and weighing on a digital scale $( \pm 0.1 \mathrm{~g})$, measuring electricity consumption during printing with a multimeter $( \pm 0.004 \mathrm{kWh})$ and assuming filament costs available on Amazon of USD 19.99/kg. When all mass and energy readings were documented, the economic comparison could be evaluated. The distributed manufacturing cost $(D)$ for a given educational aid was calculated by:

$$
D=v+m\left(\frac{f}{1000}+e\right)[\mathrm{USD}]
$$

where all costs are in U.S. dollars and $\mathrm{v}$ is the cost of the "vitamins", or any extra materials involved in making the educational aid, $\mathrm{m}$ is the mass of the printed part in grams, $\mathrm{f}$ is the filament cost per kilogram and e is the electricity cost per g printed. The electricity cost used the average of energy use per $g$ found for the Table 1 prints multiplied by the average U.S. energy cost (USD/kWh), which was taken as the U.S. Energy Information Administration average commercial rate of USD 0.1057/kWh. It should be noted that the relative impact on the total cost of printed objects due to electricity is minimal [23] so the higher electric prices in some regions or school districts would not impact the outcome.

Table 1. Educational aids 3-D printed with a description of what it does and the subject it would be used for to enhance education.

\begin{tabular}{cccc}
\hline Educational Aid & Description & Subject & Source \\
\hline Colorful Clock & Clock for teacher's aid & Math (time) & {$[65]$} \\
\hline Brain Model & A printed model of the human brain & Biology & {$[66]$} \\
\hline Pythagorean's Theorem & $\begin{array}{c}\text { Visual representation of the } \\
\text { Pythagorean theorem with triangles }\end{array}$ & Math & {$[67]$} \\
\hline Spinal Cord Model & $\begin{array}{c}\text { A model of the spinal cord with each } \\
\text { section of vertebrae color coded }\end{array}$ & Biology & {$[68]$} \\
\hline $\begin{array}{c}\text { Combustion Engine } \\
\text { Model }\end{array}$ & A moveable combustion engine & $\begin{array}{c}\text { Design and } \\
\text { Technology }\end{array}$ & {$[69]$} \\
\hline
\end{tabular}

The commercial proprietary purchase cost is dependent on the Amazon equivalent product. The marginal savings ( $S$ ) for each educational aid is determined by:

$$
S=C-D[\mathrm{USD}]
$$


where $C$ is the purchase cost of the educational aid without shipping, as all products assumed Amazon Prime membership so the shipping cost of the filament as well as the products could be ignored. The marginal percent change $(P)$ is determined by:

$$
P=\frac{(C-D)}{C} \times 100 \%
$$

The total global savings per year, Gt, for the selected aids was determined by:

$$
G_{t}=\frac{(N \times S)}{t}[\mathrm{USD}]
$$

where $t$ is the number of years a design has been available. The total global savings is thus given by $t G_{t}$.

\section{Results}

The prototypical examples from Table 1 were all successfully printed on the open-source 3-D printer and are shown in Figures 1-5. Figure 1 shows a brain model that can be used to show students the various lobes and sulci of the brain. This can be particularly useful in an anatomy or biology class. The brain is small and durable with a platform, so it can stand up on students' desks, as well as being something hand-held that can be passed around class for the children to play with and touch. The Pythagorean theorem learning aid is shown in Figure 2. This is a mathematical visual aid for students who may have a difficult time comprehending how to use this theorem. A teacher would use this when describing a problem that involves finding the hypotenuse of a right triangle. This can be used in any math or math-related class (e.g., basic engineering design) in middle and high school. A combustion engine is shown in Figure 3. This is an interactive model for students in middle school and high school to use. This model can be used in various shop classes and in introductory engineering, physics and automotive classes. It gives a visual representation of what parts interact within a combustion engine versus reading in a book about what it might look like. The clock, shown in Figure 4, is printed with a variety of colors to show that it can be used to help students learn to tell time. The numbers on the clock are large so that students can easily read them, even if they are further away from where the clock may be placed or use glasses to see. This type of learning aid can be used in elementary and middle schools. Finally, Figure 5 shows a spinal cord. This model is excellent in any physiology or biology class. Each segment of the spine is broken up by color and can be removed from the stem for students to hold. The vertebrae can be individually counted and the model provides an excellent resource for students who learn by using their hands. These aids are generally for students who may need help visualizing what is going on and prefer to actually touch things versus reading something from a textbook and looking at photos. These properties are also particularly effective for special education for visually impaired people. 3-D printed objects like the spinal cord possess haptic and tactile features that can be extremely important for educators teaching the blind.

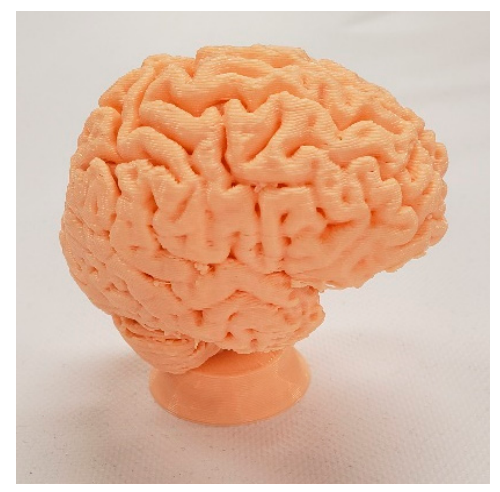

Figure 1. Human brain model [66]. 


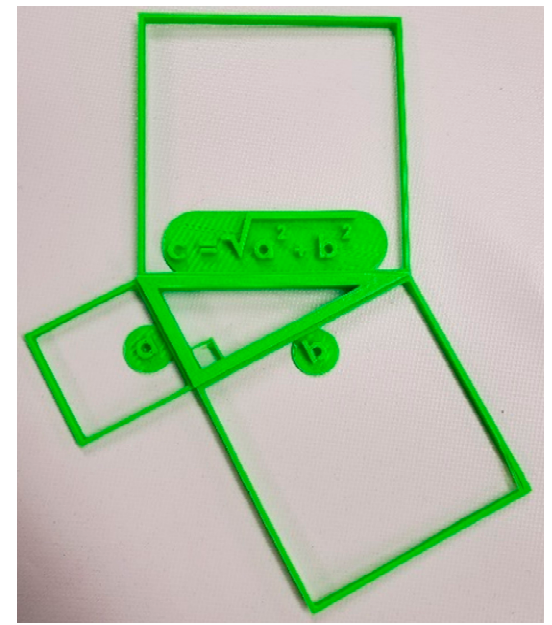

Figure 2. Pythagorean theorem model [67].

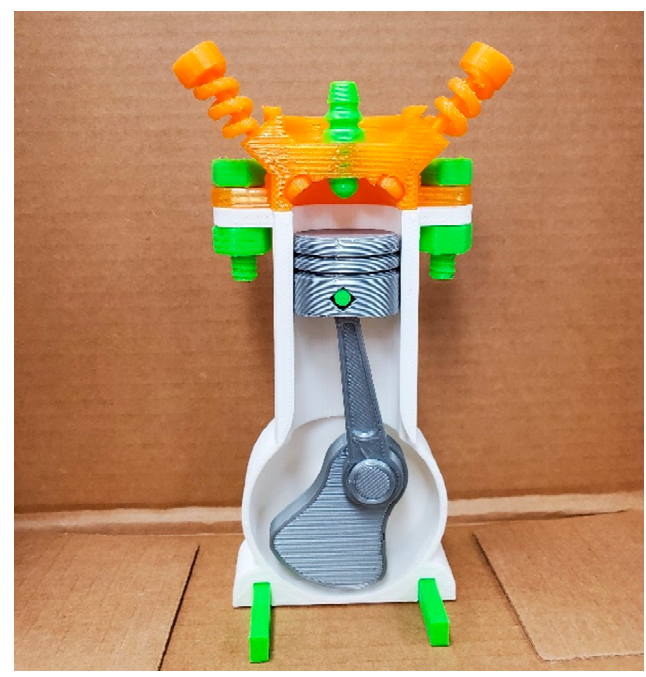

Figure 3. Combustion engine model [69].

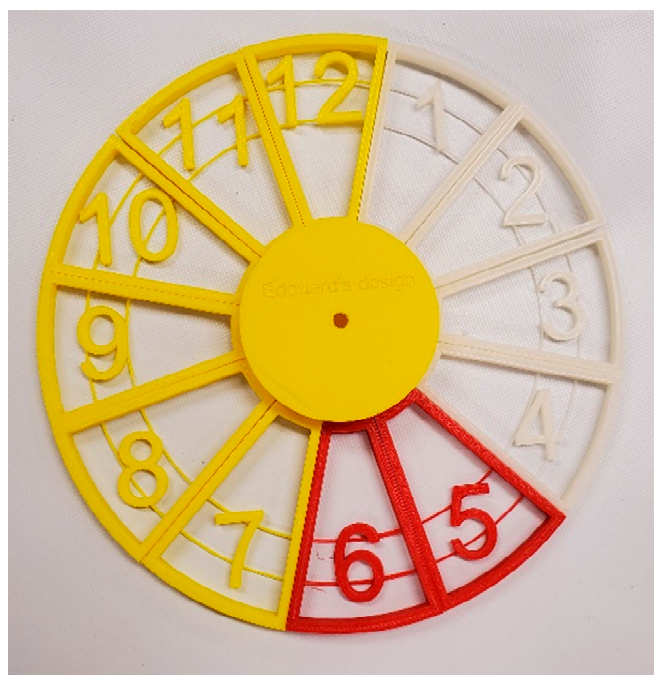

Figure 4. Clock model [65]. 


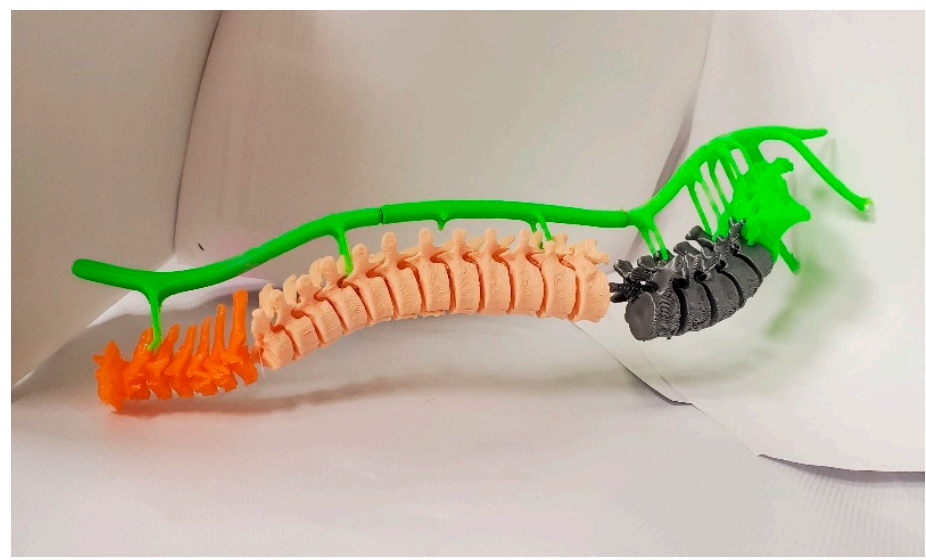

Figure 5. Spinal cord model [68].

Overall, the Cura-estimated mass was found to be highly accurate and a constant factor was not necessary to translate between estimated and measured masses. Based on the energy used and mass of the 3-D printed part measured in Table 1, the cost per kg was found to be USD 21.47 with USD 1.479/kg from electricity and USD 19.99/kg from filament material costs. The 3-D printed product total cost and the savings and saving percentages are shown for the prototypical examples in Figures 1-5 in Table 2. It can be clearly seen in Table 2 that the percent savings for the prototypical learning aids are very high $(95 \%)$ when the vitamins are minimized, but drop substantially (down to $30 \%$ for the clock) when substantial purchased components are needed to complete the assembly of the learning aid.

Table 2. Economic comparison of distributed manufacturing and commercial educational aids from measured values of prototypical aids.

\begin{tabular}{cccccc}
\hline Educational Aid & Mass (g) & $\begin{array}{c}\text { Distributed } \\
\text { Manufacturing Cost } \\
\text { (USD) }\end{array}$ & $\begin{array}{c}\text { Purchase } \\
\text { Cost (USD) }\end{array}$ & $\begin{array}{c}\text { Savings } \\
\text { (USD) }\end{array}$ & $\begin{array}{c}\text { Savings } \\
\text { (\%) }\end{array}$ \\
\hline Colorful Clock & 222.98 & 11.79 & 16.99 & 5.20 & 30.6 \\
\hline Brain Model & 52.34 & 1.12 & 58.99 & 57.87 & 98.1 \\
\hline Pythagorean Theorem & 24.60 & 0.53 & 14.74 & 14.21 & 96.4 \\
\hline Spinal Cord Model & 29.95 & 1.303 & 53.99 & 52.66 & 97.5 \\
\hline Combustion Engine Model & 99.61 & 2.14 & 45.47 & 43.33 & 95.3 \\
\hline
\end{tabular}

Then, using the value of the USD $21.47 / \mathrm{kg}$ determined from the experimental study, the 3-D printing costs were estimated based on the sliced mass for all of the teaching aids and are shown in Table 3. 
Table 3. Evaluated educational aids based on estimated printed mass and economic comparison including savings and percent savings compared to Amazon purchases.

\begin{tabular}{|c|c|c|c|c|c|}
\hline Educational Aid & $\begin{array}{c}\text { Mass of } \\
\text { Printed } \\
\text { Parts (kg) }\end{array}$ & $\begin{array}{l}\text { Total Distributed } \\
\text { Manufacturing } \\
\text { Cost (USD) }\end{array}$ & $\begin{array}{c}\text { Amazon } \\
\text { Purchase } \\
\text { Cost (USD) }\end{array}$ & $\begin{array}{l}\text { Savings } \\
\text { (USD) }\end{array}$ & $\begin{array}{c}\text { Percent } \\
\text { Savings } \\
\quad(\%)\end{array}$ \\
\hline Spirograph & 0.034 & 0.73 & 15.79 & 15.06 & $95 \%$ \\
\hline $\begin{array}{c}\text { Rubber Band-Powered } \\
\text { Airplane }\end{array}$ & 0.005 & 0.16 & 22.95 & 22.79 & $99 \%$ \\
\hline $\begin{array}{l}\text { Multi-colored Earth Core } \\
\text { Model }\end{array}$ & 0.219 & 4.70 & 16.27 & 11.57 & $71 \%$ \\
\hline Color Palette & 0.038 & 0.82 & 5.99 & 5.17 & $86 \%$ \\
\hline Multi-colored Cell Model & 0.099 & 2.13 & 15.29 & 13.16 & $86 \%$ \\
\hline Mechanical Counter & 0.187 & 4.11 & 5.99 & 1.88 & $31 \%$ \\
\hline Water Wheel & 0.186 & 3.99 & 11.99 & 8.00 & $67 \%$ \\
\hline Solar System Model & 0.066 & 1.42 & 28.97 & 27.55 & $95 \%$ \\
\hline $\begin{array}{c}\text { USA States Magnetic } \\
\text { Puzzle }\end{array}$ & 0.083 & 1.78 & 13.99 & 12.21 & $87 \%$ \\
\hline DNA Helix Model & 0.037 & 0.79 & 15.00 & 14.21 & $95 \%$ \\
\hline Hybridized Orbital & 0.025 & 0.54 & 29.00 & 28.46 & $98 \%$ \\
\hline Test Tube Holder & 0.048 & 1.03 & 15.99 & 14.96 & $94 \%$ \\
\hline $\begin{array}{c}\text { Peg Board Holder } \\
\text { Attachments/Accessories }\end{array}$ & 0.102 & 2.19 & 13.90 & 11.71 & $84 \%$ \\
\hline Screw & 0.0006 & 0.01 & 15.98 & 15.97 & $100 \%$ \\
\hline Colosseum & 0.139 & 2.98 & 16.95 & 13.97 & $82 \%$ \\
\hline Great Wall of China & 0.058 & 1.25 & 94.99 & 93.74 & $99 \%$ \\
\hline Earth Globe Model & 0.034 & 0.73 & 31.34 & 30.61 & $98 \%$ \\
\hline Mount Vesuvius & 0.042 & 0.90 & 201.49 & 00.59 & $100 \%$ \\
\hline Abacus & 0.119 & 2.55 & 9.99 & 7.44 & $74 \%$ \\
\hline $\begin{array}{c}\text { Center of Balance Finger } \\
\text { Toy }\end{array}$ & 0.01 & 0.21 & 7.48 & 7.27 & $97 \%$ \\
\hline Newton's Cradle & 0.003 & 0.06 & 25.87 & 25.81 & $100 \%$ \\
\hline $\begin{array}{l}\text { Torso Model with Partial } \\
\text { Dissection }\end{array}$ & 0.032 & 0.69 & 19.99 & 19.30 & $97 \%$ \\
\hline Periodic Table Puzzle & 0.492 & 10.56 & 22.95 & 12.39 & $54 \%$ \\
\hline DNA RNA Replication Set & 0.106 & 2.28 & 18.48 & 16.20 & $88 \%$ \\
\hline Gear Model & 0.018 & 0.39 & 12.99 & 12.60 & $97 \%$ \\
\hline Aztec Calendar & 0.101 & 2.17 & 35.99 & 33.82 & $94 \%$ \\
\hline Viking Sword & 0.157 & 3.37 & 48.99 & 45.62 & $93 \%$ \\
\hline Toronto Skyline & 0.026 & 0.56 & 2.99 & 2.43 & $81 \%$ \\
\hline The World Continents & 0.014 & 0.30 & 10.95 & 10.65 & $97 \%$ \\
\hline Star Tetrahedron & 0.037 & 0.79 & 39.90 & 39.11 & $98 \%$ \\
\hline 3D Stars & 0.007 & 0.15 & 9.39 & 9.24 & $98 \%$ \\
\hline Perpetual Motion Model & 0.062 & 10.28 & 35.99 & 25.71 & $71 \%$ \\
\hline Pendulum Wave Machine & 0.127 & 36.22 & 51.95 & 15.73 & $30 \%$ \\
\hline
\end{tabular}


As can be seen in Table 3, the same trends are observed as in Table 2. The distributed manufactured learning aids all cost substantially less than those that could be purchased from the largest online retailer in the world. The savings were higher for those products that could be $100 \% 3$-D printed. Combining the data from Tables 2 and 3, the average cost to make a learning aid was USD 3.10 and it replaced on average a USD 29.37 product, providing, on average, a saving of $86 \%$. The standard deviation on the percent savings was $19 \%$ and it should be noted that the $100 \%$ savings were rounded up from some value greater than $99.5 \%$. For example, the design that would save the most when 3-D printed was the screw, with a $99.92 \%$ savings rate. The screw can be printed in various sizes and used for different applications. The design that saved the least to self-manufacture was a pendulum wave machine (only $30.40 \%$ ), which is used for various physics applications. Overall, it is clear that 3-D printing various educational aids provides high savings in the classroom and in the school in almost any context.

It is clear that educators from around the world are already embracing the use of distributed manufacturing to produce learning aids, as demonstrated in Table 4.

Table 4. Global savings from demonstrated downloading of learning aids evaluated as a function of year and total.

\begin{tabular}{|c|c|c|c|c|c|}
\hline Education Aids & $\begin{array}{l}\text { Savings } \\
\text { (USD) }\end{array}$ & $\begin{array}{l}\text { MyMiniFactory } \\
\text { Downloads }\end{array}$ & $\begin{array}{l}\text { Years } \\
\text { Posted }\end{array}$ & $\begin{array}{l}\text { Savings per Year } \\
\text { (USD/Year) }\end{array}$ & $\begin{array}{l}\text { Total Savings } \\
\text { (USD) }\end{array}$ \\
\hline Colorful Clock & $\$ 5.20$ & 958 & 1 & 4984.32 & 4984.32 \\
\hline Brain model & $\$ 57.87$ & 2921 & 4 & $42,256.87$ & $169,027.50$ \\
\hline Pythagorean Theorem & $\$ 14.21$ & 408 & 5 & 1159.69 & 5798.44 \\
\hline Spinal Cord Model & $\$ 52.66$ & 9107 & 6 & $79,925.19$ & $479,551.12$ \\
\hline Combustion Engine Model & $\$ 43.33$ & 6280 & 5 & $54,424.46$ & $272,122.32$ \\
\hline Spirograph & $\$ 15.06$ & 9897 & 5 & $29,809.87$ & $149,049.35$ \\
\hline $\begin{array}{l}\text { Rubber Band-Powered } \\
\text { Airplane }\end{array}$ & $\$ 22.79$ & 1608 & 2 & $18,325.29$ & $36,650.59$ \\
\hline $\begin{array}{l}\text { Multi-colored Earth Core } \\
\text { Model }\end{array}$ & $\$ 11.57$ & 386 & 2 & 2232.68 & 4465.36 \\
\hline Color Palette & $\$ 5.17$ & 187 & 3 & 322.52 & 967.57 \\
\hline Multi-colored Cell Model & $\$ 13.16$ & 1176 & 2 & 7740.77 & $15,481.53$ \\
\hline Mechanical Counter & $\$ 1.88$ & 768 & 3 & 480.08 & 1440.23 \\
\hline Water Wheel & $\$ 8.00$ & 772 & 3 & 2057.83 & 6173.50 \\
\hline Solar System Model & $\$ 27.55$ & 400 & 3 & 3673.74 & $11,021.22$ \\
\hline $\begin{array}{c}\text { USA States Magnetic } \\
\text { Puzzle }\end{array}$ & $\$ 12.21$ & 219 & 4 & 668.39 & 2673.57 \\
\hline DNA Helix Model & $\$ 14.21$ & 550 & 3 & 2604.37 & 7813.11 \\
\hline Hybridized Orbital & $\$ 28.46$ & 153 & 3 & 1451.63 & 4354.88 \\
\hline Test Tube Holder & $\$ 14.96$ & 92 & 3 & 458.76 & 1376.27 \\
\hline $\begin{array}{c}\text { Peg Board Holder } \\
\text { Attachments/Accessories }\end{array}$ & $\$ 11.71$ & 2526 & 4 & 7394.97 & $29,579.87$ \\
\hline Screw & $\$ 15.97$ & 3470 & 5 & $11,081.18$ & $55,405.90$ \\
\hline Colosseum & $\$ 13.97$ & 5002 & 5 & $13,971.40$ & $69,856.98$ \\
\hline Great Wall of China & $\$ 93.74$ & 197 & 1 & $18,467.73$ & $18,467.73$ \\
\hline Earth Globe Model & $\$ 30.61$ & 1385 & 3 & $14,131.64$ & $42,394.92$ \\
\hline
\end{tabular}


Table 4. Cont.

\begin{tabular}{|c|c|c|c|c|c|}
\hline Education Aids & $\begin{array}{l}\text { Savings } \\
\text { (USD) }\end{array}$ & $\begin{array}{l}\text { MyMiniFactory } \\
\text { Downloads }\end{array}$ & $\begin{array}{l}\text { Years } \\
\text { Posted }\end{array}$ & $\begin{array}{l}\text { Savings per Year } \\
\text { (USD/Year) }\end{array}$ & $\begin{array}{l}\text { Total Savings } \\
\text { (USD) }\end{array}$ \\
\hline Mount Vesuvius & $\$ 200.59$ & 345 & 3 & $23,067.65$ & $69,202.96$ \\
\hline Abacus & $\$ 7.44$ & 577 & 6 & 715.02 & 4290.10 \\
\hline $\begin{array}{c}\text { Center of Balance Finger } \\
\text { Toy }\end{array}$ & $\$ 7.27$ & 710 & 3 & 1719.46 & 5158.37 \\
\hline Newton's Cradle & $\$ 25.81$ & 1275 & 2 & $16,451.07$ & $32,902.13$ \\
\hline $\begin{array}{l}\text { Torso Model with Partial } \\
\text { Dissection }\end{array}$ & $\$ 19.30$ & 1533 & 2 & $14,795.74$ & $29,591.49$ \\
\hline Periodic Table Puzzle & $\$ 12.39$ & 370 & 3 & 1527.76 & 4583.28 \\
\hline DNA RNA Replication Set & $\$ 16.20$ & 201 & 3 & 1085.69 & 3257.06 \\
\hline Gear Model & $\$ 12.60$ & 711 & 6 & 1493.52 & 8961.13 \\
\hline Aztec Calendar & $\$ 33.82$ & 2725 & 2 & $46,081.97$ & $92,163.94$ \\
\hline Viking Sword & $\$ 45.62$ & 389 & 5 & 3549.19 & $17,745.93$ \\
\hline Toronto Skyline & $\$ 2.43$ & 87 & 3 & 70.52 & 211.57 \\
\hline The World Continents & $\$ 10.65$ & 163 & 5 & 347.17 & 1735.86 \\
\hline Star Tetrahedron & $\$ 39.11$ & 89 & 3 & 1160.13 & 3480.40 \\
\hline 3D Stars & $\$ 9.24$ & 121 & 4 & 279.50 & 1118.01 \\
\hline Perpetual Motion Model & $\$ 25.71$ & 2152 & 3 & $18,441.87$ & $55,325.60$ \\
\hline Pendulum Wave Machine & $\$ 15.73$ & 107 & 2 & 841.74 & 1683.48 \\
\hline
\end{tabular}

The average learning aid evaluated in this study had been downloaded over 1500 times over an average of 3.42 years since it was open sourced and posted. The average savings per year per learning aid were USD 11,822 and, overall, the 38 learning aids evaluated in this study saved about USD 450,000/year. To date, the average saving per learning aid was thus over USD 45,000 and the aggregate of just 38 learning aids saved the international educational community over USD 1.7 million.

\section{Discussion}

\subsection{Limitations of the Study}

There are several limitations to this study. First, the utility of a given educational aid may vary widely in a given classroom and thus the limited selection of aids evaluated here may not be representative for all classrooms. Future work could address this by evaluating more designs but also doing field work to see how 3-D printers are being used in the classroom-specifically those purchased to fabricate educational aids. Another limitation is that not all schools have the initial capital to invest in a 3-D printer. The model used here retails for USD 2500 and is considered a mid-range fused filament fabrication (FFF)-based 3-D printer. Open-source FFF-based 3-D printers can be purchased for 10 times less, and even less if built in kit form. Previous work has shown that these lower cost 3-D printers would be expected to be capable of printing all of the designs evaluated [23]. The major difference is the lower cost printers tend to have a smaller print bed and, for particularly large prints, the model would need to be divided into several parts and then assembled afterwards with tabs or some form of adhesive. In addition, it should be noted that because some of these lower cost 3-D printers do not have heated beds, the distributed manufacturing costs would be slightly lower. Another limitation of this study is that only one material-PLA — was evaluated. It is the one of the safest and best choices for filament, especially around young children; however, other choices of filament could be more durable (e.g., nylon) or more cost-effective and better for the environment (e.g., recycled materials [70-72]), 
depending on the print. It should also be noted that with the nozzle and filament diameter size, a small amount of error occurs within the print, with the larger nozzles providing faster print times but cannot produce fine detail and vice versa. Another source of errors is when taking the Cura-estimated mass of the material. There could be slight error, as Cura rounds to the nearest gram. This could throw some of the calculations off when determining how much is being saved and how much filament is actually being used. Finally, this class of 3-D printer is not foolproof. If a print fails for any reason (e.g., nozzle clog, lack of bed adhesion, etc.), then filament is wasted. Previous studies estimated this failure rate for new printer users at 20\% [23], however, the modern self-bed leveling printers have errors far below this. The error rate will depend on the complexity of the print but can be estimated to be in the single digits when using guaranteed printable designs, as was done in this study. It should be noted, however, that the lowest cost 3-D printers that lack a heated bed can increase the probability of print failures from a lack of bed adhesion due to contraction as the part cools during printing. For some polymers, this can be a substantial problem (e.g., polypropylene should not be printed without a heated bed and best results are found with a heated chamber). For PLA, which was used in this study, printing on an unheated bed does not pose any substantial issues, particularly if a common glue stick is used to lay down a thin film before printing to ensure adhesion.

\subsection{Limitations of Deployment}

One of the primary limitations on the further deployment of 3-D printers in schools in the U.S., to take advantage of the distributed manufacturing of learning aids, is the teachers' lack of control over computers in their classrooms. Often, IT departments have strict rules for what can be downloaded on the teachers' computers. Therefore, having access to the open-source (and free) tool chain (e.g., FreeCAD, OpenSCAD or Blender for design [73]; Cura or Slic3r for slicing [74] and PrintRun or Franklin [75] for printer control) can be non-trivial for teachers to implement in the classroom even if they have the technical competency to download and set up the software on their personal computer at home. One approach to overcome this challenge is to make a library of designs specifically for teachers that are pre-sliced and available for specific printers (e.g., an SD card for education). One open-source 3-D printer manufacturer has already attempted to go down this route in part-Prusa Research is developing their prusaprinters.org website. Prusa users can post the gcode for their designs so that less experienced users can download the gcode and print directly without slicing. This, however, does not then make use of the rest of the open-source 3-D printer community that is not using a Prusa and runs the risk of machine damage. Future work is needed to develop such libraries specifically for educational aids to help teachers and perhaps bundle them with commercial open-source 3-D printers when sold in the education market.

\subsection{Teacher Training}

Teachers will also need to be trained on how to use a 3-D printer $[48,49]$, as well as incorporate it into their classroom. The training process for the teachers can be formal, as in a full university course on additive manufacturing, or a 3-day workshop in which teachers learn how to build, maintain and use an open-source 3-D printer from scratch (i.e., [48]). This level of detail, however, is unnecessary for basic use and maintenance. Creality, an open-source 3-D printer manufacturer, estimates that it takes 30 min of using free online videos for someone already familiar with 3-D printers to get their Ender 3 model (USD 170) up and running, but 2-3 h for a completely inexperienced person [76]. As the cost of low-end 3-D printers has come down, more and more students are being exposed to them at home and could be deputized to help set up a classroom 3-D printer. This relatively low level of depth would only enable a teacher to print out pre-designed teaching aids. This is the assumption used in this study and provides access to thousands of learning aids. In order to go further and be able to modify existing designs that were not made parametric or create completely new designs, however, learning CAD (computer aided design) would be necessary. CAD education ranges from a full university course to a self-paced free tutorial (e.g., EduTech [77] or FreeCAD [78]) that could be accomplished over several 
intense hours or a more leisurely "learning weekend". Fully mastering any of the open-source CAD packages would normally take several months of practice after learning the basics but, again, this is unnecessary to get started. Finally, with the skills to run the printers, teachers would also need to think about the best way to incorporate them into their own classrooms. So, for example, if students are getting distracted, prints can be run while they are at recess, at lunch or overnight/on the weekend. Future work is also needed to reduce the volume of printers during the printing process. It should also be pointed out here that at many schools and universities, the 3-D printing shops are run by an experienced technician. For example, a library might employee an expert 3-D printing employee to enable teachers with minimal training in CAD and additive manufacturing (AM) to obtain learning aids or the help they need to do it themselves without formal training.

\subsection{Values and Costs}

The benefits of centralized large-scale manufacturing are well established in the literature and historically have included reduced costs due to the economies of scale, from: (i) bulk purchasing of materials, supplies and components through large and long-term contracts; (ii) technological advantages of returns to scale in the production function, such as lower embodied energy during manufacturing of a given product because of scale (e.g., injection molding plastic products); (iii) favorable financing in terms of interest, access to capital and a variety of financial instruments; (iv) centralized marketing and (v) increased specialization of employees and managers [79,80]. These advantages of mass-scale centralized manufacturing have created a general trend towards large-scale manufacturing in low-labor cost countries, especially for inexpensive plastic products $[81,82]$. As the results of this study show, the centralized paradigm is no longer economically competitive because of the advances in distributed manufacturing technology for some products (e.g., learning aids manufactured from plastic). Although this has been pointed out in the literature for other products as detailed in the introduction, the new and rigorously detailed results shown in this study are still somewhat surprising.

Table 5. The costs and values for a teaching aid from the teacher's perspective (a red symbol indicates a disadvantage for the teacher/consumer while a green symbol indicates an advantage).

\begin{tabular}{|c|c|c|c|c|}
\hline Item & $\begin{array}{c}\text { Mass Manufactured } \\
\text { Cost }\end{array}$ & $\begin{array}{c}\text { Mass Manufactured } \\
\text { Value }\end{array}$ & $\begin{array}{c}\text { Self-Fabricated } \\
\text { Cost }\end{array}$ & $\begin{array}{c}\text { Self-Fabricated } \\
\text { Value }\end{array}$ \\
\hline Design (e.g., R\&D) & & & & \\
\hline Intellectual Property & & NA & & NA \\
\hline Materials & & & & \\
\hline $\begin{array}{l}\text { Fabrication/Manufacturing } \\
\text { (labor + energy }+ \\
\text { percentage equipment } \\
\text { time) }\end{array}$ & & & & \\
\hline Packaging & & NA & & NA \\
\hline
\end{tabular}


Table 5. Cont.

\begin{tabular}{|c|c|c|c|c|}
\hline Item & $\begin{array}{c}\text { Mass Manufactured } \\
\text { Cost }\end{array}$ & $\begin{array}{c}\text { Mass Manufactured } \\
\text { Value }\end{array}$ & $\begin{array}{c}\text { Self-Fabricated } \\
\text { Cost }\end{array}$ & $\begin{array}{c}\text { Self-Fabricated } \\
\text { Value }\end{array}$ \\
\hline Shipping & & NA & & NA \\
\hline Retail & & NA & & NA \\
\hline Advertising & & NA & & NA \\
\hline Management & & NA & & NA \\
\hline Financing & & NA & & NA \\
\hline Profit & & NA & & NA \\
\hline Warranty & & & & \\
\hline
\end{tabular}

Critics will point out that this study is equating the costs of production with the costs of retailing and may argue that it is not a fair comparison. From the teacher's perspective, however, the cost to obtain a learning aid is the full cost that matters to their supplies budget and the value is only what they acquire in the classroom. To clarify the economic position and provide some insight into why it is less costly to manufacture a learning aid in the classroom than buy a mass-manufactured product, Table 5 shows the costs and values from the teacher's perspective for (1) the typical mass-manufactured proprietary product and (2) the distributed self-fabricated open-source products. Each item making up the cost will then be discussed in turn. In Table 5, the green symbols represent a benefit and the red symbols represent a disadvantage for the consumer (e.g., teacher) and the check marks indicate that the item is present while the $X$ indicates that it is not. Thus, the ideal system would have all green marks ( $X$ for costs and checks for values).

As can be seen in Table 5, the self-fabricated open-source approach has nearly all of the advantages seen but considerably fewer disadvantages than the mass-manufactured model. This explains in large part why the results of this study found that distributed manufacturing would result in considerable savings for teachers (consumers).

The cost of the research and development (R\&D) in the standard model is borne by the company to create the design that benefits the consumer. In the open-source model, however, this same benefit is gained at no cost because the learning aid is open source and developed by someone else. In addition, considerable costs are shouldered by the traditional company for intellectual property (IP) protection, which has no direct benefit to the consumer for a given product. For example, even companies like Apple, that are known for innovation, spend more on lawyers than engineers [83]. On the other hand, there is no IP cost for the open-source self-fabrication model.

The conventional mass-manufacturing company has a substantial advantage in the cost of materials because of bulk purchasing. Assuming identical materials (i.e., plastic) the self-fabricated cost for the materials will be greater (e.g., USD 20/kg for retail 3-D printing filament vs. USD 1-5/kg for bulk plastic) and the value will be the same. Similarly, to fabricate the product, in both cases, the consumer benefits from the product produced and there is a cost associated with the making. This cost is generally divided into labor, energy and equipment costs. The labor costs for the traditional manufacturer is higher as it is essentially free to self-fabricate a pre-designed product on a 3-D printer. 
On the other hand, the energy cost would be expected to be larger for the self-fabricator because of the economy of scale advantage for the mass manufacturer. Similarly, the mass manufacturer, although using larger and more expensive equipment (e.g., an injection molding machine), would produce far more copies, thus the machine cost per product would be expected to be lower for mass manufacturing. 3-D printers and the cost in electricity to operate them is so small [23] that neither of these advantages for mass-manufacturing play a major role in the cost of a product.

Next, there are several costs that must be included in a mass-manufactured product that offer the consumer no advantage, which are unnecessary with the open-source approach, including: packaging, shipping, retail (e.g., store costs, online or brick and mortar), advertising, management, financing and profit for the company. Some of these costs can be quite substantial and others represent a disadvantage for the consumer. First, not only are packaging costs eliminated for self-fabricated products, but the consumer also saves time in unpacking items. Packaging waste and difficulty in opening some products are a source of frustration for consumers $[84,85]$. Second, shipping costs are not only eliminated (assuming 3-D printing feed stock is on hand because it can be purchased ahead of time) but, in general, the print time for a learning aid will be less than the order/ship time for a mass-manufactured product (e.g., the print times for the products here are in the order of hours, while shipping is normally in the order of days). This, again, saves the consumer time, which is a value. The costs associated with the overhead and profit of retail establishments are also all completely eliminated. This is true of the online retailers that need to pay for servers, programmers, etc., but even more so for brick and mortar stores. It is estimated that the markups for retailers were 10\% for Costco, 15\% for Amazon, 32\% for Walmart and $46 \%$ for Target [86]. The costs for advertising and marketing are completely eliminated for the self-fabrication model, while advertising represents a time cost and source of frustration for consumers who attempt to protect their time [87] (e.g., some of the most popular plugins for both Firefox [88] and Chrome Internet browsers [89] are for ad blocking software, which have been downloaded tens of millions of times and have saved consumers enormous amounts of time and money by conserving energy to run their computers to service ads [90]). The management costs to run large corporations have swollen [91,92] even when the company is failing [93] and, again, these are not needed in the distributed model. Similarly, financing and profit only add costs to the mass-manufactured model, while they are not needed in the distributed model.

Finally, the mass manufactured products undergo usability, durability and safety testing that enables companies to provide some form of warranty. This has value for the consumer, which is not captured in the self-fabricated approach. This is the one area that may prevent a given product from providing an equivalent value to a mass-manufactured item. This area is most important for products that are likely to fail due to complexity or have a long lifespan. For the products evaluated here made out of plastic and often lacking moving parts, this is unlikely to be a major concern (e.g., would a teacher rather pay less than one USD for a spirograph set he or she can make in class on his or her 3-D printer or pay over USD 15 to buy one from Amazon even if it comes with a warranty?). Future work is needed to determine the value for the consumer for the explicit or implicit warranties (e.g., Amazon returns) for mass-manufactured products.

Overall, it is clear that although mass manufacturing enjoys advantages in material and energy costs compared to the self-fabrication model, it is not enough to overcome all of the other cost disadvantages, which is why the cost to the consumer (e.g., teacher) was found to be so much lower than the retail cost for the teaching and learning aids investigated here. 


\subsection{Overall Economics and Advanced Applications}

Despite both this study's limitations and those of the concept of distributed manufacturing in schools with 3-D printers in general, it is clear that fabricating learning aids in the classroom is economic. Even for the relatively expensive 3-D printer used, printing even 100 aids on average would pay for itself. This could easily be accomplished in the "first 100 days" of class. Further, with each teaching aid, on average, that is 3-D printed, the school saves the cost of an entire roll of filament. These savings are clearly substantial and, as seen from Table 4, the technique appears to be already being used throughout the world by teachers or other educators trying to help their students understand concepts. It is quite remarkable that, on average, a given open-source educational aid is saving well over ten thousand U.S. dollars per year for the educational community. This value uses the assumption that for each download, one item is printed, following [94]. It does not take, in general, USD 10,000 worth of engineering time to produce a learning aid. This thus provides a return on investment (ROI) for investors hoping to improve education, on average, of more than $100 \%$ [95]. The ROI is so high that it could be justified even in a single school that uses any substantial number of copies of a learning aid. Particularly if these are for more advanced science classes, like optomechanical systems [96], micropumping [97], bioadhesion [98] or bioreactors [99]. The savings that, on average, are $86 \%$ for learning aids would go a long way at a school that makes use of learning aids, but perhaps more importantly, with the costs being accessible, more teachers would be likely to use them and the teaching at a school would be improved. This needs further study and is left for future work.

In addition, 3-D printing enables economic access to the ability for schools to integrate special education students using advanced applications. For example, there are open-source parametric 3-D printable designs for Braille patterns developed in OpenSCAD [100]. This script-based computer-aided design is extremely effective at teaching students both to code and the value of math [48], but in this context, it can be used to have students directly help their blind peers learn. This could be a powerful learning motivation and means to better integrate blind and visually impaired students into classrooms. There are already many ways 3-D printers can be used to help blind and visually impaired students, including tactile maps, illustrations for books, learning games and artwork [101]. Fabricating learning aids and even assistive aids for blind and visually impaired students with 3-D printers can make economic learning aids for art teaching [102], but can also get quite functionally sophisticated. For example, a low-cost, open source ultrasound-based navigational support system in the form of a 3-D printable wearable bracelet has been demonstrated to allow people with vision loss to navigate, orient themselves in their surroundings and avoid obstacles when moving. Similarly, research has already shown the efficacy of 3-D printing to create orally disintegrating printlets (ODPs), suitable for patients with visual impairment, with Braille and Moon patterns on their surface, enabling patients to identify medications when taken out of their original packaging [103]. Students may start printing learning aids and Braille labels for peers, but as they become more technically sophisticated, fabricating ultrasound-based navigational aids from open-source plans or ODPs is possible and no longer economically inaccessible. Future work is needed to look closely at this area on both technical and economic grounds.

3-D printers in the classroom can have other ancillary benefits. The opportunity to print objects now can give students something to look forward to when coming to school [48]. They can become more interested in the STEM field [44,45]. Additionally, students could design their own objects that can be made for classrooms or younger children to help proactive learners. In general, students that are first exposed to 3-D printers love to watch the printer work its magic and make objects. Young students ask questions about the printer, such as "How hot does it get to melt the plastic?" and "How does it know how to print what we want?". Students are curious about the machine itself and would touch the print bed or the filament. 3-D printers (or even using them) could be used as prizes or awards for good student behavior or achievements. Finally, it could lead students who have already graduated to give back to the schools they grew up in following the open-source model $[27,28]$. This equipment in 
the classroom gives the school a higher sense of technology. This may ultimately boost educational quality (e.g., ratings), attracting more students (e.g., funding).

\section{Conclusions}

This study successfully analyzed the economics of classroom-based 3-D printing of open-source digital designs of learning aids for the classroom itself. The results show current open-source 3-D printers are more than capable of manufacturing useful learning aids. Further, this distributed manufacturing for education will save schools money. The average substitution of a purchase of a learning aid for one that is 3-D printed saves more than the cost of a $1 \mathrm{~kg}$ spool of commercial filament. Overall, the average learning aid would save teachers $86 \%$ by fabricating it themselves. Even for relatively expensive commercial 3-D printers, a school could save the cost of the investment in the first 100 days of class. It is clear that 3-D printing various educational aids provides high savings in the classroom and in the school in almost any context.

This study also provided preliminary evidence that educators from around the world are already embracing the use of distributed manufacturing to produce learning aids. The results show that the average learning aid evaluated in this study was downloaded over 1500 times and presumably printed as many times. The average savings per year per open-source learning aid design was USD 11,822 and, overall, the 38 learning aids evaluated in this study saved about USD 450,000/year. To date, the 38 learning aids evaluated in this study have, on average, produced a saving per learning aid of over USD 45,000 and the total of all of them has saved the international educational community over USD 1.7 million to date. It is clear that investing in the development of open-source learning aids for students provides a return on investment (ROI) for investors hoping to improve education, on average, of more than $100 \%$. Finally, future work is needed to develop libraries of open-source designs specifically for educational aids to help teachers and perhaps bundle them with commercial open-source 3-D printers when sold in the education market.

Author Contributions: Conceptualization, J.M.P.; methodology, J.M.P.; validation, N.G. and J.M.P.; formal analysis, N.G. and J.M.P.; investigation, N.G. and J.M.P; resources, J.M.P; data curation, N.G. writing-original draft preparation, N.G. and J.M.P.; writing — review and editing, N.G. and J.M.P.; visualization, N.G.; supervision, N.G. and J.M.P.; funding acquisition, J.M.P. All authors have read and agreed to the published version of the manuscript

Funding: This work was supported by the Witte Endowment and Aleph Objects.

Acknowledgments: The authors would like to thank S. Gallup for helpful discussions and feedback.

Conflicts of Interest: The authors declare no conflict of interest. The funders had no role in the design of the study; in the collection, analyses, or interpretation of data; in the writing of the manuscript, or in the decision to publish the results. 


\section{Appendix A}

Table A1. Source file uniform resource locators (URLs) at MyMiniFactory.

\begin{tabular}{|c|c|}
\hline Aid & MyMiniFactory URL \\
\hline Colorful Clock & https://www.myminifactory.com/object/3d-print-3d-printable-clock-54723 \\
\hline Spirograph & https://www.myminifactory.com/object/3d-print-spirograph-11148 \\
\hline Rubber Band-Powered Airplane & https://www.myminifactory.com/object/3d-print-rubber-band-powered-plane-69535 \\
\hline Multi-colored Earth Core Model & https://www.myminifactory.com/object/3d-print-multi-color-earth-core-model-60813 \\
\hline Color Palette & https://www.myminifactory.com/object/3d-print-color-palette-36424 \\
\hline Multi-colored Cell Model & https://www.myminifactory.com/object/3d-print-multi-color-cell-model-43020 \\
\hline Mechanical Counter & https://www.myminifactory.com/object/3d-print-mechanical-counter-31952 \\
\hline Water Wheel & https://www.myminifactory.com/object/3d-print-education-working-overshot-water-wheel-25733 \\
\hline Solar System Model & https://www.myminifactory.com/object/3d-print-sun-and-planets-to-scale-with-accurate-saturn-rings-39565 \\
\hline USA States Magnetic Puzzle & https://www.myminifactory.com/object/3d-print-usa-states-magnetic-puzzle-set-21935 \\
\hline Brain Model & https://www.myminifactory.com/object/3d-print-human-brain-11053 \\
\hline DNA Helix Model & https://www.myminifactory.com/object/3d-print-dna-helix-29733 \\
\hline Hybridized Orbital & https://www.myminifactory.com/object/3d-print-hybridized-orbitals-33823 \\
\hline Peg Board Holder Attachments/Accessories & https://www.myminifactory.com/object/3d-print-manhattan-pegboard-collection-for-3d-printers-18332 \\
\hline Screw & https://www.myminifactory.com/object/3d-print-screw-3436 \\
\hline Colosseum & https://www.myminifactory.com/object/3d-print-colosseum-10646 \\
\hline Great Wall of China & https://www.myminifactory.com/object/3d-print-great-wall-of-china-74401 \\
\hline Earth Globe Model & https://www.myminifactory.com/object/3d-print-wired-earth-globes-27033 \\
\hline Mount Vesuvius & https://www.myminifactory.com/object/3d-print-mount-vesuvius-39582 \\
\hline Abacus & https://www.myminifactory.com/object/3d-print-abacus-1297 \\
\hline
\end{tabular}


Table A1. Cont.

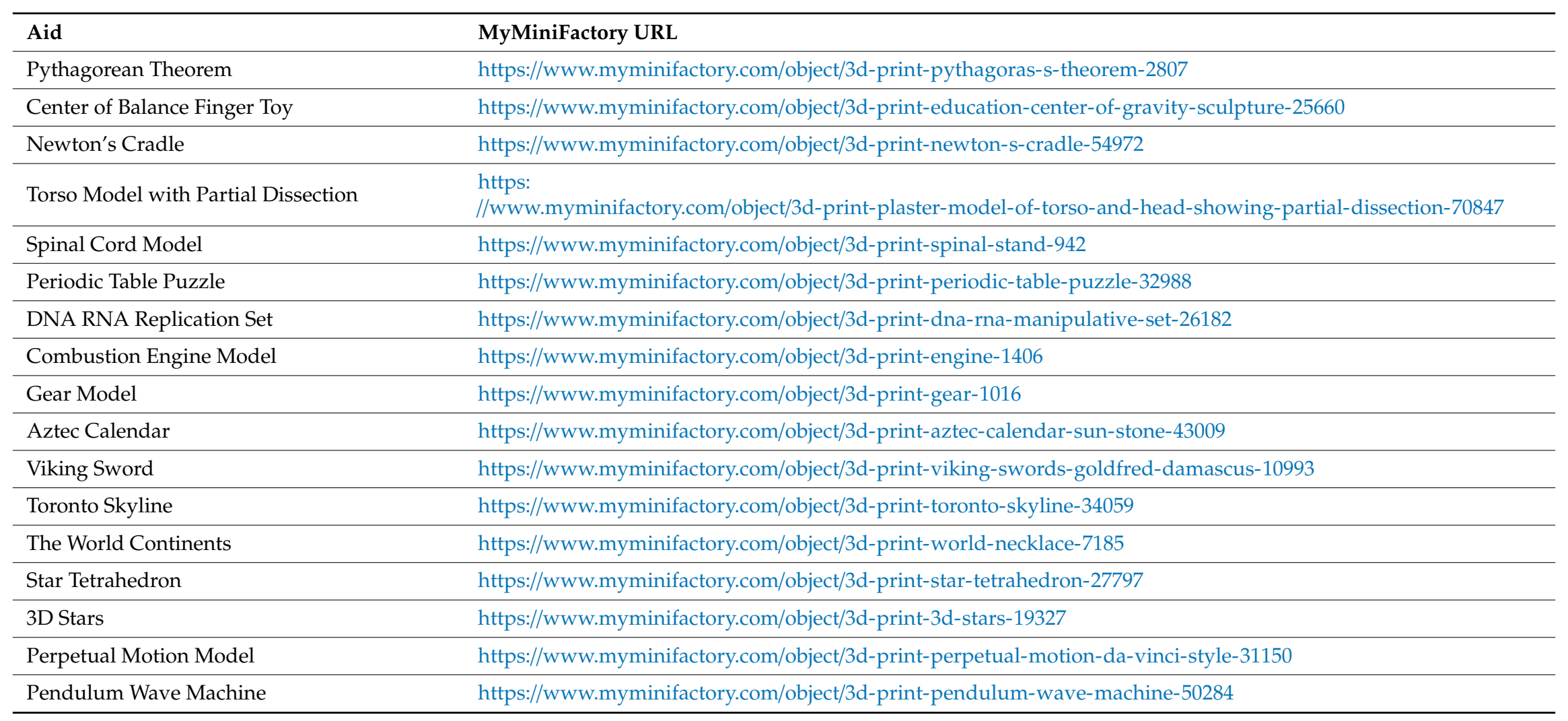


Table A2. Source file uniform resource locators (URLs) at Amazon.

\begin{tabular}{|c|c|}
\hline Aid & Amazon URL \\
\hline Colorful Clock & https://www.amazon.com/45Min-Teaching-Movement-Educational-Classroom/dp/B07G6P5R1B/ \\
\hline Spirograph & https://www.amazon.com/Spirograph-01001-S-Deluxe-Design-Set/dp/B009VE38CI/ \\
\hline Multi-colored Earth Core Model & https://www.amazon.com/Learning-Resources-Cross-Section-Earth-Model/dp/B00069ATQ0/ \\
\hline Color Palette & https://www.amazon.com/Artlicious-Palettes-Acrylic-Watercolor-Brushes/dp/B07281X9RY/ \\
\hline Multi-colored Cell Model & https://www.amazon.com/Learning-Resources-Cross-Section-Animal-Model/dp/B000FS4LWK/ \\
\hline Mechanical Counter & https://www.amazon.com/HORSKY-Counter-Handheld-Mechanical-Clicker/dp/B071W3QTBX/ \\
\hline Water Wheel & https://www.amazon.com/Small-World-Toys-Sand-Water/dp/B000CBWVW2/ \\
\hline Solar System Model & https://www.amazon.com/Educational-Insights-Geosafari-Motorized-Science/dp/B01MT47ZWF/ \\
\hline USA States Magnetic Puzzle & https://www.amazon.com/Learning-Resources-Magnetic-Puzzle-Pieces/dp/B01MU4SA6K/ \\
\hline Brain Model & https://www.amazon.com/Anatomically-Accurate-Anatomy-Classroom-Teaching/dp/B07R6S83K7/ \\
\hline DNA Helix Model & https://www.amazon.com/Helix-Crystal-Statue-Inches-Height/dp/B00H58FN8Y/ \\
\hline Hybridized Orbital & https://www.amazon.com/Molecular-Models-16-PH657-Platinum-Expansion/dp/B013LMDV1I \\
\hline Test Tube Holder & https://www.amazon.com/Black-Plastic-Bottles-Toothbrush-Display/dp/B07889B4S6/ \\
\hline Peg Board Holder Attachments/Accessories & https://www.amazon.com/Pegboard-Bins-Accessories-Attachments-Workbench/dp/B071GLLP5N/ \\
\hline Screw & https://www.amazon.com/Skoolzy-Nuts-Bolts-Motor-Skills/dp/B00WKZAO7C/ \\
\hline Colosseum & https://www.amazon.com/Fascinations-ICONX-Roman-Colosseum-Metal/dp/B06XBQVY5R \\
\hline Great Wall of China & https://www.amazon.com/Great-Wall-China-Model-Kit/dp/B001F9XF70/ \\
\hline Earth Globe Model & https://www.amazon.com/Learning-Resources-Puzzle-Globe-Pieces/dp/B01MZ3Y8JV/ \\
\hline Mount Vesuvius & https://www.amazon.com/Eisco-Volcano-Mountain-Table-Approx/dp/B00UZCINT8/ \\
\hline Abacus & https://www.amazon.com/SALKOGREEN-Classic-Soroban-Abacus-Kids/dp/B07N1318L9/ \\
\hline Pythagorean Theorem & https://www.amazon.com/Didax-Educational-Resources-Pythagorean-Theorem/dp/B01D94R6HI/ \\
\hline Center of Balance Finger Toy & https://www.amazon.com/Toysmith-4035-Balancing-Eagle-7-Inch/dp/B004R6VB2E/ \\
\hline
\end{tabular}


Table A2. Cont.

\begin{tabular}{|c|c|}
\hline Aid & Amazon URL \\
\hline Newton's Cradle & https://www.amazon.com/FAXADELLA-Holographic-Newtons-Cradle-Wooden/dp/B01HIWKILI/ \\
\hline Torso Model with Partial Dissection & https://www.amazon.com/Learning-Resources-Human-Body-Model/dp/B0012OELR6/ \\
\hline Spinal Cord Model & https://www.amazon.com/Didactic-Colored-Flexible-Anatomical-Medical/dp/B00RLTKG8E/ \\
\hline Periodic Table Puzzle & https://www.amazon.com/ETA-hand2mind-Periodic-Chemistry-Connecting/dp/B07F2DRWLT/ \\
\hline DNA RNA Replication Set & https://www.amazon.com/Molymod-W19761-RNA-Base-Kit/dp/B005NWG6DU/ \\
\hline Combustion Engine Model & https://www.amazon.com/American-Educational-Plastic-Gasoline-Engine/dp/B006581HZS/ \\
\hline Gear Model & https://www.amazon.com/Atomik-RC-Hardened-Center-Traxxas/dp/B00ARWVTNI/ \\
\hline Aztec Calendar & https://www.amazon.com/Ebros-Xiuhpohualli-Tonalpohualli-Sculpture-Mesoamerican/dp/B014HY4FQO/ \\
\hline Viking Sword & https://www.amazon.com/Viking-Style-Battle-Ready-Inches/dp/B014RW3PS0/ \\
\hline Toronto Skyline & https://www.amazon.com/Toronto-SkyLine-Title-Canada-Magnet/dp/B01LXV3N49/ \\
\hline The World Continents & https://www.amazon.com/World-Map-USA-Kids-LAMINATED/dp/B076BDVCCW/ \\
\hline Star Tetrahedron & https://www.amazon.com/Shungite-Merkaba-Black-Carving-Sacred/dp/B073WHR6F1/ \\
\hline 3D Stars & https://www.amazon.com/Twinkle-Star-Hanging-Banner-Decoration/dp/B07793QZHX/ \\
\hline Perpetual Motion Model & https://www.amazon.com/DjuiinoStar-Low-Temperature-Stirling-Engine/dp/B077LHS81K/ \\
\hline Pendulum Wave Machine & https://www.amazon.com/American-Scientific-Pendulum-Decoration-Incredible/dp/B014EAUSGC/ \\
\hline
\end{tabular}




\section{References}

1. Mehrotra, S.; DelaMonica, E. Household costs and public expenditure on primary education in five low income countries: A comparative analysis. Int. J. Educ. Dev. 1998, 18, 41-61. [CrossRef]

2. Feldman, S. Children in Crisis: The Tragedy of Underfunded Schools and the Students They Serve. Am. Educ. Prof J. Am. Fed. Teach. 1992, 16, 8.

3. Freelon, R.; Bertrand, M.; Rogers, J. Overburndened and Underfunded: California Public Schools Amidst the Great Recession. Multidiscip. J. Educ. Res. 2012, 2, 152-176. [CrossRef]

4. Danvers, K. The Effects of Underfunded Legislative Mandates on Fiscal Stability of School Districts. J. High. Educ. Theory Pract. 2019, 19. [CrossRef]

5. Krausen, K.; Willis, J. Silent Recession-Why California School Districts are Underwater Despite Increases in Funding. 2018, p. 28. Available online: https://www.wested.org/resources/silent-recession/ (accessed on 26 November 2020).

6. SSI. School Specialty Reports Fiscal; Financial Results: Greenville, WI, USA, 2007.

7. Rulianto, A.; Yasa, E.S. Teacher Durori's Learning Aid. In Indonesia's Weekly News Magazine; Tempo Inti Media: Jakarta, Indonesia, 2002.

8. King, A. The Technology Factor: Nine Keys to Student Achievement and Cost-Effectiveness. Proj. Red 2010, 180. Available online: https://www.k12blueprint.com/sites/default/files/Project-RED-Technolgy-Factor.pdf (accessed on 26 November 2020).

9. Gershenfeld, N. How to make almost anything: The digital fabrication revolution. Foreign Aff 2012, 91, 43.

10. Laplume, A.O.; Petersen, B.; Pearce, J.M. Global Value Chains from a 3D Printing Perspective. J. Int. Bus. Stud. JIBS Lit. Rev. Arch. 2016, 47, 595-609. [CrossRef]

11. Gwamuri, J.; Wittbrodt, B.T.; Anzalone, N.C.; Pearce, J.M. Reversing the Trend of Large Scale and Centralization in Manufacturing: The Case of Distributed Manufacturing of Customizable 3-D-Printable Self-Adjustable Glasses. Chall. Sustain. 2014, 2, 30-40. [CrossRef]

12. Campbell, I.; Diegel, O.; Kowen, J.; Wohlers, T. Wohlers Report 2018: 3D Printing and Additive Manufacturing State of the Industry: Annual Worldwide Progress Report; Wohlers Associates: Fort Collins, CO, USA, 2018.

13. Piller, F.T.; Weller, C.; Kleer, R. Business Models with Additive Manufacturing-Opportunities and Challenges from the Perspective of Economics and Management. In Proceedings of the Advances in Production Technology; Brecher, C., Ed.; Springer International Publishing: Cham, Switzerland, 2015; pp. 39-48.

14. Matias, E.; Rao, B. 3D printing: On its historical evolution and the implications for business. In Proceedings of the 2015 Portland International Conference on Management of Engineering and Technology (PICMET), Portland, OR, USA, 2-6 August 2015; pp. 551-558.

15. Laplume, A.; Anzalone, G.C.; Pearce, J.M. Open-source, self-replicating 3-D printer factory for small-business manufacturing. Int. J. Adv. Manuf. Technol. 2016, 85, 633-642. [CrossRef]

16. Hoy, M.B. 3D Printing: Making Things at the Library. Med. Ref. Serv. Q. 2013, 32, 93-99. [CrossRef]

17. Massis, B.E. 3D printing and the library. New Libr. World 2013, 114, 351-354. [CrossRef]

18. Moorefield-Lang, H. Makers in the library: Case studies of 3D printers and maker spaces in library settings. Libr. Hi Tech 2014, 32, 583-593. [CrossRef]

19. Walter-Herrmann, J.; Büching, C. (Eds.) FabLab: Of Machines, Makers and Inventors; Transcript Verlag: Bielefeld, Germany, 2014.

20. Byard, D.J.; Woern, A.L.; Oakley, R.B.; Fiedler, M.J.; Snabes, S.L.; Pearce, J.M. Green fab lab applications of large-area waste polymer-based additive manufacturing. Addit. Manuf. 2019, 27, 515-525. [CrossRef]

21. Van Holm, E.J. Makerspaces and Local Economic Development. Econ. Dev. Q. 2017, 31, 164-173. [CrossRef]

22. Petrick, I.J.; Simpson, T.W. 3D printing disrupts manufacturing: How economies of one create new rules of competition. Res.-Technol. Manag. 2013, 56, 12-16. [CrossRef]

23. Wittbrodt, B.T.; Glover, A.G.; Laureto, J.; Anzalone, G.C.; Oppliger, D.; Irwin, J.L.; Pearce, J.M. Life-cycle economic analysis of distributed manufacturing with open-source 3-D printers. Mechatronics 2013, 23, 713-726. [CrossRef]

24. Ishengoma, F.R.; Mtaho, A.B. 3D printing: Developing countries perspectives. arXiv 2014, arXiv:1410.5349.

25. Petersen, E.E.; Pearce, J. Emergence of Home Manufacturing in the Developed World: Return on Investment for Open-Source 3-D Printers. Technologies 2017, 5, 7. [CrossRef] 
26. Shewbridge, R.; Hurst, A.; Kane, S.K. Everyday making: Identifying future uses for 3D printing in the home. In Proceedings of the 2014 Conference on Designing Interactive Systems, Vancouver, BC, Canada, 21-25 June 2014; pp. 815-824.

27. Parker, S. Opening Up to Open Source. Richmond J. Law Technol. 2000, 6, 24.

28. Gibb, A.; Abadie, S. Building Open Source Hardware: DIY Manufacturing for Hackers and Makers; Pearson Education: Upper Saddle River, NJ, USA, 2014.

29. Oberloier, S.; Pearce, J.M. General Design Procedure for Free and Open-Source Hardware for Scientific Equipment. Designs 2018, 2, 2. [CrossRef]

30. Jones, R.; Haufe, P.; Sells, E.; Iravani, P.; Olliver, V.; Palmer, C.; Bowyer, A. RepRap-The replicating rapid prototyper. Robotica 2011, 29, 177-191. [CrossRef]

31. Sells, E.; Smith, Z.; Bailard, S.; Bowyer, A.; Olliver, V. RepRap: The Replicating Rapid Prototyper: Maximizing Customizability by Breeding the Means of Production. Handb. Res. Mass Cust. Pers. 2010, 1. [CrossRef]

32. Bowyer, A. 3D Printing and Humanity's First Imperfect Replicator. 3D Print. Addit. Manuf. 2014, 1, 4-5. [CrossRef]

33. Ford, S.; Minshall, T. Invited Review Article: Where and How 3D Printing is Used in Teaching and Education. Addit. Manufacturing 2019, 25, 131-150. [CrossRef]

34. Lim, K.H.A.; Loo, Z.Y.; Goldie, S.J.; Adams, J.W.; McMenamin, P.G. Use of 3D printed models in medical education: A randomized control trial comparing 3D prints versus cadaveric materials for learning external cardiac anatomy. Anat. Sci. Educ. 2016, 9, 213-221. [CrossRef]

35. Garcia, J.; Yang, Z.; Mongrain, R.; Leask, R.L.; Lachapelle, K. 3D printing materials and their use in medical education: A review of current technology and trends for the future. BMJ Simul. Technol. Enhanc. Learn. 2018, 4. [CrossRef]

36. Vaccarezza, M.; Papa, V. 3D printing: A valuable resource in human anatomy education. Anat. Sci. Int. 2015, 90, 64-65. [CrossRef]

37. Smith, M.L.; Jones, J.F.X. Dual-extrusion 3D printing of anatomical models for education. Anat. Sci. Educ. 2018, 11, 65-72. [CrossRef]

38. Cook, K.L.; Bush, S.B.; Cox, R. Creating a prosthetic hand: 3D printers innovate and inspire a maker movement. Sci. Child. 2015, 53, 80.

39. Buehler, E.; Comrie, N.; Hofmann, M.; McDonald, S.; Hurst, A. Investigating the implications of 3D printing in special education. ACM Trans. Access. Comput. (TACCESS) 2016, 8, 1-28. [CrossRef]

40. Neumüller, M.; Reichinger, A.; Rist, F.; Kern, C. 3D Printing for Cultural Heritage: Preservation, Accessibility, Research and Education. In 3D Research Challenges in Cultural Heritage: A Roadmap in Digital Heritage Preservation; Ioannides, M., Quak, E., Eds.; Lecture Notes in Computer Science; Springer: Berlin/Heidelberg, Germany, 2014; pp. 119-134. ISBN 978-3-662-44630-0.

41. Horowitz, S.S.; Schultz, P.H. Printing Space: Using 3D Printing of Digital Terrain Models in Geosciences Education and Research. J. Geosci. Educ. 2014, 62, 138-145. [CrossRef]

42. Gonzalez-Gomez, J.; Valero-Gomez, A.; Prieto-Moreno, A.; Abderrahim, M. A New Open Source 3D-Printable Mobile Robotic Platform for Education. In Proceedings of the Advances in Autonomous Mini Robots; Rückert, U., Joaquin, S., Felix, W., Eds.; Springer: Berlin/Heidelberg, Germany, 2012; pp. 49-62.

43. Martin, R.L.; Bowden, N.S.; Merrill, C. 3D Printing in Technology and Engineering Education. Technol. Eng. Teach. 2014, 73, 30-35.

44. Easley, W.; Buehler, E.; Hurst, A.; Salib, G. Fabricating Engagement: Benefits and Challenges of Using 3D Printing to Engage Underrepresented Students in STEM Learning. In Proceedings of the 2017 ASEE Annual Conference \& Exposition, Columbus, OL, USA, 25-28 June 2017.

45. Coakley, M.F.; Hurt, D.E.; Weber, N.; Mtingwa, M.; Fincher, E.C.; Alekseyev, V.; Chen, D.T.; Yun, A.; Gizaw, M.; Swan, J.; et al. The NIH 3D print exchange: A public resource for bioscientific and biomedical 3D prints. 3D Print. Addit. Manuf. 2014, 1, 137-140. [CrossRef] [PubMed]

46. Mercuri, R.T.; Meredith, K. An educational venture into 3D Printing. In Proceedings of the 2014 IEEE Integrated STEM Education Conference, Princeton, NJ, USA, 8 March 2014. [CrossRef]

47. Canessa, E.; Fonda, C.; Zennaro, M. Low-cost 3D printing for science, education and sustainable development. Low-Cost 3D Printing 2013. Available online: http://sdu.ictp.it/3D/book.html (accessed on 26 November 2020).

48. Schelly, C.; Anzalone, G.C.; Wijnen, B.; Pearce, J.M. Open-Source 3-D Printing Technologies for Education: Bringing Additive Manufacturing to the Classroom. J. Vis. Lang. Comput. 2015, 28, 226-237. [CrossRef] 
49. Verner, I.; Merksamer, A. Digital Design and 3D Printing in Technology Teacher Education. Procedia CIRP 2015, 36, 182-186. [CrossRef]

50. Wang, B.; Sud, R.; Leung, M.; Yang, M.; Rodriguez, J.A.; Lee, R.; Cappelli, M. OpenEM-Electromagnetic field mapping robot for microwave and RF measurements. HardwareX 2019, 5, e00062. [CrossRef]

51. Lupetti, M.L. Shybo. An open-source low-anthropomorphic robot for children. HardwareX 2017, 2, 50-60. [CrossRef]

52. Alves-Oliveira, P.; Arriaga, P.; Paiva, A.; Hoffman, G. Guide to build YOLO, a creativity-stimulating robot for children. HardwareX 2019, 6, e00074. [CrossRef]

53. Chen, M.; Zhang, Y.; Zhang, Y. Effects of a 3D printing course on mental rotation ability among 10-year-old primary students. Int. J. Psychophysiol. 2014, 2, 240. [CrossRef]

54. Corum, K.; Garofalo, J. Using Digital Fabrication to Support Student Learning. 3D Print. Addit. Manuf. 2015, 2, 50-55. [CrossRef]

55. Maloy, R.; Trust, T.; Kommers, S.; Malinowski, A.; LaRoche, I. 3D Modeling and Printing in History/Social Studies Classrooms: Initial Lessons and Insights. Contemp. Issues Technol. Teach. Educ. 2017, 17, 229-249.

56. Craddock, I.L. Makers on the move: A mobile makerspace at a comprehensive public high school. Libr. Hi Tech 2015. [CrossRef]

57. Kostakis, V.; Niaros, V.; Giotitsas, C. Open source 3D printing as a means of learning: An educational experiment in two high schools in Greece. Telemat. Inform. 2015, 32, 118-128. [CrossRef]

58. Eisenberg, M. 3D printing for children: What to build next? Int. J. Child-Comput. Interact. 2013, 1, 7-13. [CrossRef]

59. MyMiniFactory. Available online: https://www.myminifactory.com/ (accessed on 26 November 2020).

60. Kotha, S. Competing on the Internet: The case of Amazon. com. Eur. Manag. J. 1998, 16, 212-222. [CrossRef]

61. Zhu, F.; Liu, Q. Competing with complementors: An empirical look at Amazon. com. Strateg. Manag. J. 2018, 39, 2618-2642. [CrossRef]

62. Weise, K. Prime Power: How Amazon Squeezes the Businesses Behind Its Store; The New York Times: New York, NY, USA, 2019.

63. Tokiwa, Y.; Calabia, B.P.; Ugwu, C.U.; Aiba, S. Biodegradability of Plastics. Int. J. Mol. Sci. 2009, 10, $3722-3742$. [CrossRef] [PubMed]

64. Wittbrodt, B.; Pearce, J. The Effects of PLA Color on Material Properties of 3-D Printed Components. Addit. Manuf. 2015, 8. [CrossRef]

65. 3D Printable Clock by Edouard Spiers. Available online: https://www.myminifactory.com/object/3d-print-3d -printable-clock-54723 (accessed on 26 November 2020).

66. 3D Printable Human Brain by Vaclav Krmela. Available online: https://www.myminifactory.com/object/3dprint-human-brain-11053 (accessed on 26 November 2020).

67. 3D Printable Pythagorean Theorem by Cristiano Maci. Available online: https://www.myminifactory.com/ob ject/3d-print-pythagoras-s-theorem-2807 (accessed on 26 November 2020).

68. 3D Printable Spinal Stand by MyMiniFactory. Available online: https://www.myminifactory.com/object/3dprint-spinal-stand-942 (accessed on 26 November 2020).

69. 3D Printable Combustion Engine by Jack Imakr. Available online: https://www.myminifactory.com/object/3 d-print-engine-1406 (accessed on 26 November 2020).

70. Zhao, P.; Rao, C.; Gu, F.; Sharmin, N.; Fu, J. Close-looped recycling of polylactic acid used in 3D printing: An experimental investigation and life cycle assessment. J. Clean. Prod. 2018, 2018 197, 1046-1055. [CrossRef]

71. Kreiger, M.A.; Mulder, M.L.; Glover, A.G.; Pearce, J.M. Life cycle analysis of distributed recycling of post-consumer high density polyethylene for 3-D printing filament. J. Clean. Prod. 2014, 70, 90-96. [CrossRef]

72. Zhong, S.; Pearce, J. Tightening the loop on the circular economy: Coupled distributed recycling and manufacturing with recyclebot and RepRap 3-D printing. Resour. Conserv. Recycl. 2018, 128, 48-58. [CrossRef]

73. Junk, S.; Kuen, C. Review of Open Source and Freeware CAD Systems for Use with 3D-Printing. Procedia CIRP 2016, 50, 430-435. [CrossRef]

74. Horvath, J. Mastering 3D Printing; Apress: New York, NY, USA, 2014.

75. Wijnen, B.; Anzalone, G.; Haselhuhn, A.; Sanders, P.; Pearce, J. Free and open-source control software for 3-D motion and processing. J. Open Res. Softw. 2016, 4, e2. 
76. Creality. Official Creality Ender 3 3D Printer, Official Ender 3 3d Printer Store-Official Store for Creality 3D Printers and Accessories. 2020. Available online: https://www.creality3dofficial.com/products/official-creali ty-ender-3-3d-printer (accessed on 8 October 2020).

77. Edutech. OpenScad Beginners Tutorial-EduTech Wiki. 2020. Available online: http://edutechwiki.unige.ch /en/OpenScad_beginners_tutorial (accessed on 8 October 2020).

78. FreeCADweb. Basic Modeling Tutorial—FreeCAD Documentation. 2020. Available online: https://wiki.freec adweb.org/Basic_modeling_tutorial (accessed on 8 October 2020).

79. Mukherjee, S. Modern Economic Theory; New Age International: Delhi, India, 2002.

80. Miltenburg, J. Manufacturing Strategy: How to Formulate and Implement a Winning Plan; CRC Press: Boca Raton, FL, USA, 2005.

81. Kravis, I.B.; Lipsey, R.E. The location of overseas production and production for export by US multinational firms. J. Int. Econ. 1982, 12, 201-223. [CrossRef]

82. Ruamsook, K.; Russell, D.; Thomchick, E. US sourcing from low-cost countries: A comparative analysis of supplier performance. J. Supply Chain Manag. 2007, 43, 16-30. [CrossRef]

83. Trenholm, R. Apple Spends more on Patents than R\&D after Jobs Patent Vow. 2012. Available online: https://www.cnet.com/news/apple-spends-more-on-patents-than-r-d-after-jobs-patent-vow/ (accessed on 8 November 2020).

84. Griffith-Greene, M. 'Wrap Rage' Experienced by most Canadians|CBC News. 2014. Available online: https: //www.cbc.ca/news/business/excessive-packaging-dangerous-frustrating-for-consumers-poll-1.2490047 (accessed on 8 November 2020).

85. Bird, J. What A Waste: Online Retail's Big Packaging Problem. 2018. Available online: https://ww w.forbes.com/sites/jonbird1/2018/07/29/what-a-waste-online-retails-big-packaging-problem/ (accessed on 8 November 2020).

86. Aslin, A. Retail Markups and the Power of Amazon, Market Watch. 2012. Available online: http://blog s.marketwatch.com/great-columnist/2012/10/15/retail-markups-and-the-power-of-amazon/ (accessed on 1 November 2015).

87. Milne, G.R.; Boza, M.E. Trust and Concern in Consumers' Perceptions of Marketing Information Management Practices. J. Interact. Mark. 1999, 13, 5-24. [CrossRef]

88. Miller, F. 14 Best Mozilla Firefox Add-ons, Apps \& Extensions of 2020 Product. Land. Available online: https://productivityland.com/best-firefox-add-ons-extensions/ (accessed on 23 February 2020).

89. Spadafora, A. These Are the most Popular Google Chrome extensions. Tech. Radar. 2019. Available online: https://www.techradar.com/news/most-popular-google-chrome-extensions (accessed on 22 February 2020).

90. Pearce, J.M. Energy Conservation with Open Source Ad Blockers. Technologies 2020, 8, 18. [CrossRef]

91. Mishel, L.; Sabadish, N. CEO pay and the top 1\%. Econ. Policy Inst. Issue Brief 2012, 331, 1-7.

92. Burton, J.A.; Weller, C.E. Supersize this: How CEO pay took off while America's middle class struggled; Center for American Progress: Washington, DC, USA, 2005.

93. Henderson, M.T. Paying CEOs in bankruptcy: Executive compensation when agency costs are low. Nw. UL Rev. 2007, 101, 1543. [CrossRef]

94. Pearce, J. Quantifying the Value of Open Source Hardware Development. Mod. Econ. 2015, 6, 1-11. [CrossRef]

95. Pearce, J.M. Return on investment for open source scientific hardware development. Sci. Public Policy 2016, 43, 192-195. [CrossRef]

96. Winters, B.J.; Shepler, D. 3D printable optomechanical cage system with enclosure. HardwareX 2018, 3, $62-81$. [CrossRef]

97. Bravo-Martinez, J. Open source 3D-printed $1000 \mu \mathrm{L}$ micropump. HardwareX 2018, 3, 110-116. [CrossRef]

98. Vaut, L.; Scarano, E.; Tosello, G.; Boisen, A. Fully replicable and automated retention measurement setup for characterization of bio-adhesion. HardwareX 2019, 6, e00071. [CrossRef]

99. Romero-Morales, A.I.; O'Grady, B.J.; Balotin, K.M.; Bellan, L.M.; Lippmann, E.S.; Gama, V. Spin $\infty:$ An updated miniaturized spinning bioreactor design for the generation of human cerebral organoids from pluripotent stem cells. HardwareX 2019, 6, e00084. [CrossRef] [PubMed]

100. Kahler, A. Braille OpenSCAD Font Module. Available online: https://www.thingiverse.com/thing:4758 (accessed on 8 October 2020).

101. Watkin, H. 10 Ways 3D Printing Supports the Blind. All3DP. 2016. Available online: https://all3dp.com/3d-pr inting-supporting-blind-people/ (accessed on 8 October 2020). 
102. Knochel, A.D.; Hsiao, W.H.; Pittenger, A. Touching to see: Tactile learning, assistive technologies, and 3-D printing. Art Educ. 2018, 71,7-13. [CrossRef]

103. Awad, A.; Yao, A.; Trenfield, S.J.; Goyanes, A.; Gaisford, S.; Basit, A.W. 3D Printed Tablets (Printlets) with Braille and Moon Patterns for Visually Impaired Patients. Pharmaceutics 2020, 12, 172. [CrossRef]

Publisher's Note: MDPI stays neutral with regard to jurisdictional claims in published maps and institutional affiliations.

(C) 2020 by the authors. Licensee MDPI, Basel, Switzerland. This article is an open access article distributed under the terms and conditions of the Creative Commons Attribution (CC BY) license (http://creativecommons.org/licenses/by/4.0/). 